\title{
Real Men Use Nonlethals
}

\section{Appeals to Masculinity in Marketing Police Weaponry}

\author{
Jesse Wozniak \\ Christopher Uggen \\ University of Minnesota, Minneapolis
}

\begin{abstract}
In recent years, a range of new nonlethal weapons have been introduced for use by police officers, military personnel, and other consumers. This article examines how manufacturers are employing ideals of masculinity as both physical dominance and technical expertise in marketing these weapons to police officials. Based on a case study of a major weapons manufacturer's educational and sales conference, the authors explore how marketing appeals are adapted to suit a hypermasculine police subculture. Connell's theory of masculinities is employed to understand how such a tightly defined subculture absorbs challenges to its core values of hegemonic hypermasculinity and reimagines itself to keep those core values intact.
\end{abstract}

Keywords: weapons; policing; masculinity; Connell; justice; stun guns; conducted energy device; police habitus; gender and policing

$\mathrm{P}$ olice officers have historically viewed themselves as a "thin blue line" protecting the public from the "bad guys" of the world (Skolnick \& Fyfe, 1993). In return for their protection, modern democratic societies have granted police a "virtual monopoly" on the legitimate use of force on civilians (Reiss, 1971, p. 2). Since the early 1970s, however, police departments have increasingly employed formal bureaucratic procedures to regulate police use of force. When officers employ violence in their work, they are now subject to written rules mandating formal reports that are reviewed by senior officials. Moreover, a more restrictive "defense of life" standard has now replaced the more permissive "fleeing felon" standard for the use of deadly force by officers (Skogan \& Frydl, 2004, p. 284).

Increased regulation has been driven, in part, by threats to police legitimacy. More than 26,000 citizen complaints about police use of force were received by large law enforcement agencies in 2002, a rate of more than 10 per 100 full-time sworn officers responding to calls for service (U.S. Department of Justice, Bureau of Justice Statistics, 2006). Moreover, public opinion evidence suggests that citizens

Authors'Note: Please address correspondence to Jesse Wozniak, 909 Social Sciences Tower, Minneapolis, MN 55455; e-mail: wozni019@umn.edu. 
are becoming increasingly critical of police use of force. According to U.S. General Social Survey data, a declining percentage of Americans approve of a police officer striking a male citizen for any reason (J. A. Davis \& Smith, 2007). About $75 \%$ of men had responded affirmatively to this question in 1970 and about $73 \%$ responded affirmatively in 2003. For women, however, support dropped more precipitously, from more than $70 \%$ in 1970 to only 60\% in 2003 (authors' calculations available by request). In the face of citizen complaints and calls for accountability, law enforcement increasingly has turned to "soft" or nonlethal forms of weaponry. Specifically designed to avoid killing or permanently injuring their targets, nonlethal weapons lack the firepower of sidearms and shotguns. Yet despite their increased regulation, firearms remain central to officers' visions of themselves and their work (Herbert, 2001). Those seeking to market nonlethal weapons to the police must therefore address a fundamental question: How does one sell a "soft" weapon to a "hard" cop?

To answer this question, the first author attended an educational and sales conference presented by a major nonlethal weapons maker and analyzed several manufacturers' Web sites and marketing materials. Although they employ diverse marketing strategies, the manufacturers send a consistent message: that nonlethal weapons are masculine and, hence, wholly consistent with traditional police ideals of toughness, power, and control through coercive force. In light of the gender diversity in law enforcement today, we did not anticipate that appeals to masculinity would play such a central role in marketing nonlethal weapons. Yet after emerging from the field, the conclusion was inescapable. As we will explain below, the conference and online materials provide fitting sites to examine gendered appeals in contemporary policing (Miller, 1998; Texeira, 2002; Zimmer, 1987), while revealing the durable and fluid nature of the construction of masculinity (Connell, 1995). The bulk of the conference was seemingly predicated on proving, developing, and substantiating the masculinity of nonlethal weapons and resolving the competing forms of hegemonic masculinity invoked in introducing such weapons. This task was achieved by highlighting the masculine aspects of the use of force, presenting idealized images of the police, legitimizing evidence, and identifying police as "heroes" while discrediting perceived "villains" who would sabotage their interests.

\section{Nonlethal Weapons}

Nonlethal weapons have played an important role throughout the history of policing, with the British Bobbies and their billy clubs constituting the bestknown example (Silver, 1967; Spitzer \& Scull, 1982). Nevertheless, nonlethal weapons more advanced than the club or primitive forms of pepper spray are a recent innovation in the criminal justice field. Serious development of many nonlethal technologies did not begin in earnest until the mid-1990s (Rappert, 2003), 
when President Clinton appointed a commission to research the development and plausibility of nonlethals for federal use. In 1997, the Joint Nonlethal Weapons Program was established, setting guidelines, standards, requirements, and capabilities of nonlethals for military use.

Nonlethal weapons come in myriad forms, from pepper sprays and other chemical irritants to projectile nets and acoustic weaponry designed to disorient individuals. Although nearly every police department in the United States deploys some form of nonlethal weaponry, the use of the conducted energy device (CED), commonly referred to as the "stun gun," has been the most controversial.

Today, CEDs have become one of the most common nonlethal weapons deployed by police, with the StunCo stunner (the fictionalized name of the company and product discussed in this article) emerging as one of the most popular CEDs available. The stunner alone is deployed by thousands of U.S. police agencies and has been shipped to dozens of nations, generating annual sales of hundreds of thousands of units and more than 50 million dollars in annual revenues. CEDs are likely to remain one of the most common nonlethal weapons for quite some time, as "second-generation" nonlethals (such as acoustics, direct energy, and laser-based weapons) remain in the developmental stages (Rappert, 2003). Furthermore, as the firm's CEO reported at the conference, StunCo is in discussion with U.S. armed forces to develop nonlethal weapons for military combat. In a remark that critical criminologists might interpret as indicating a "prison-industrial complex" (A. Davis \& Dent, 2001), the CEO even characterized such developments as "the future of modern warfare."

Nevertheless, there is extensive debate surrounding the use of CEDs in law enforcement and their deployment during events such as the 1999 World Trade Organization protest in Seattle (Wozniak, 2004). Although some people see them as a more humane method for dealing with recalcitrant suspects than standard police tactics, others counter that too little is known about such powerful weapons. For critics, CEDs may be no more humane, but simply more palatable to a distrusting public. Most notably, Amnesty International and the American Civil Liberties Union (ACLU) have raised serious questions about the safety and widespread use of CEDs. Amnesty, for example, claims that the use of CEDs has resulted in more than 150 deaths since 2001, calling for a moratorium on their use until further testing has been completed (Hibberd, 2006), a call that has been echoed by academics (e.g., Lewer \& Davison, 2005). Furthermore, Amnesty reports that weapons of this type have been exported to nations with questionable human rights records, where they may be used to torture political dissidents (Amnesty International USA, 2006). Although they may represent a humane alternative in some settings, CEDs are also well suited for torture; they cause extreme pain (and possibly death), yet leave only two small red bumps where the electrodes are attached to the skin, which disappear after a few days. They can thus be deployed with impunity, as it is very difficult to prove they have ever been used. Other researchers have raised similar concerns about the impacts of CEDs on civil rights based on their use against peaceful demonstrators (Lewer, 1999; Lewer \& Davison, 2005). 


\section{Masculinity and the Police Subculture}

A long line of research (Kappeler, Sluder, \& Alpert, 1994; Reiss, 1971; Steffans, 1931/2005; Wilson, 2000) has identified a strong and durable police subculture, which is distinct from other heavily investigated subcultures in that it forms a totalizing police normative order (Herbert, 1998) or habitus (Bourdieu, 1977) for those within it. In many cases, officers' colleagues, friends, and even their families are overwhelmingly composed of fellow officers (Harris, 1973; Niederhoffer, 1969). Because of this social isolation, Skolnick (1966) suggests that all officers adopt the "beliefs and definitions" of the department, regardless of the individual differences they may have had before joining the force. As one former police chief has written, “civilians don't, and perhaps can't, understand cops" (Bouza, 1990, p. 5). This closed-off world is reinforced by the fact that few outsiders penetrate the system because nearly all officers at all ranks have worked their way up from basic patrol.

Among the oft-noted values of the police habitus are such stereotypically masculine qualities as strength, stoicism, loyalty, and obedience to hierarchy. Masculinity is deeply valued within the police culture, perhaps representing the defining concept of the officer's world. In their participant observation study of a law enforcement academy, for example, Prokos and Padavic (2002) show how hegemonic masculinity shapes the professional socialization of police officers from their very first moments of police training (see also Beauchesne, 2001; Harris, 1973; Uhnak, 1963). Whether it is celebrating fighting or downplaying putatively feminized aspects of police work (such as paperwork and social service provision), the police academy sends a clear message that policing is "men's work." As such, police departments have remained "remarkably stable, white, [and] male" (Bouza, 1990, p. 34, 142) and can be conceived of as "gendered institutions" (Acker, 1990; Carr, Hudson, Hanks, \& Hunt, 2008; Martin, 1980).

For gender scholars such as Connell (1995), the police are privileged in part by virtue of their extreme adherence to a singular vision of heterosexual masculinity. Moreover, the police operate within a broader gender system that privileges this vision of masculinity. Strong adherence to hegemonic masculinity leads to stark dichotomies in how the police view both their work and the outside world. Officers make a strong distinction between the masculinized "warriors" on the street and the "station queens" in the offices, with the latter label used to feminize officers who are perceived to lack the toughness required for street patrol (Herbert, 1998, 2001). The same distinction applies to those outside the force with whom police interact. As we discuss below, street criminals are portrayed as hypermasculine bad guys, whereas outsiders such as politicians and critics of police are criticized as unmasculine. Similarly, almost all measures of outside control (judicial reviews, civilian review boards, etc.) are resisted and derided as "antipolice" (Westley, 1970).

Other scholars have noted this strong connection between the police world and hegemonic hypermasculinity. Enloe (1993), for example, employs the term "militarism" to 
speak of the creeping spread of militaristic values into nonmilitary institutions. This has an important connection to masculinity, as "to be manly means to be a potential warrior" (Enloe, 1993, p. 52). Militarism, however, is not simply a privileging of masculine characteristics, but necessarily implies a scorn of all things feminine (Caulfield, 2001). Kraska (1996) integrates this concept into the police world and argues that the "durable and structured" nature of militarism creates a "habitus of masculinity" and a "habitus of militarism" (p. 423) both within the police as an institution and within the officers themselves. Other scholars (e.g., Kappeler et al., 1994) similarly argue for the centrality of male solidarity in the police and other militaristic subcultures.

These and other attributes of the police habitus support Connell's (1995) conception of hegemonic masculinity. For Connell, "everyday life is an arena of gender politics" (p. 3). Gendering is not a specific type of social practice but, rather, a way of structuring social practice. As such, it interacts and intersects with other social processes, such as police training and practice. All these various police identities and values-from violence to sexism and heterosexism (Bernstein, Kostelac, \& Gaarder, 2003; Miller, Forest, \& Jurik, 2003), and the need to be "where the action is" - can all be interpreted as creating and reinforcing the hypermasculinity that marks the police habitus.

Connell (1995) emphasizes that masculinities are not given and static but, rather, evolving and historically contingent. Furthermore, when crisis tendencies in the gendered order begin to occur, "hegemonic masculinity is likely to be thematized" (Connell, 1995, p. 213). Over time, however, hegemonic masculinity (just as the other hegemonic ideologies of specific eras) has changed and shifted to fit the prevailing mood. For our purposes, the masculine portrayal of nonlethal weapons at the manufacturer's convention, as well as on the Web site and in marketing materials described below, seemed to occur against a backdrop of hegemonic gender construction. Stated more strongly, it is difficult to imagine a nonlethal weapon penetrating this important market unless it is presented and understood as an appropriately masculine technology.

\section{Framing StunCo}

CEDs are unusual among police armaments in that many departments allow their officers to carry the weapon, but because of their cost and controversial history, do not provide them to officers. Unlike most police weaponry, officers often purchase the CED personally and it is their individual decision to carry it. As such, although stunners are marketed toward departments as a whole, the task of the StunCo conference is to convince individual officers to purchase StunCo weapons. If successful, the officers might then serve as emissaries who could persuade other officers and/or their superiors that the products are needed for the rest of the force as well.

In selling to individual officers, StunCo makes appeals to the masculinity of the police habitus discussed above; however, it is not enough to simply satisfy the 
individual officer. Because StunCo is trying to make the stunner a staple of the police arsenal, a host of other parties, identified explicitly or acknowledged implicitly during the conference, must also be convinced as to the stunner's feasibility and safety. If it was only necessary to persuade the officer on the street, weapons manufacturers could simply build bigger and more powerful weapons (e.g., Jefferson, 1990), and those that are aimed specifically at paramilitary units often do so (Kraska, 1996).

Unfortunately for StunCo, in attempting to introduce a new weapon into the standard issue, they must also appease decision makers who are both budget conscious and averse to the threat of lawsuits. There are also independent third-party monitors, such as Amnesty International, Human Rights Watch, and the ACLU, who must be convinced that the weapon is safe and poses no serious risk of misuse. In light of these constraints, StunCo must somehow establish that the weapon is safe and nonlethal, and will not harm the rights and liberties of anyone they attempt to apprehend-but at the same time persuade officers that it is the weapon of choice for "real cops," who are, of course, "real men."

Connell (1995) identified similar tensions in appeasing diverse constituents and audiences, particularly the tension between physical dominance and technical expertise. This conference and the message crafted around the stunner can then be seen as StunCo's attempt to merge these two visions of masculinity. Rather than a more powerful form of firearm or a technologically advanced replacement, the stunner resolves the tension by blending upper-management public relations with streetlevel domination.

StunCo presents their CED as the ideal-typical postmodern weapon. It will cause no harm, it will leave no permanent mark, and it will be safe to use on all people in all situations. The stunner is presented as extremely powerful but also extremely safe, representing a new class of weapons designed to meet administrative and bureaucratic prerogatives as well as delivering effective force to the officer on the street. Importantly, however, it is also portrayed as the most masculine option available to meet these diverse needs. In short, it is the new weapon for a new penology of risk control (Feeley \& Simon, 1992).

\section{The StunCo Conference ${ }^{1}$}

How does StunCo go about satisfying these myriad constituencies and competing imperatives? In May 2006, the first author attended a StunCo Incorporated Convention, located in a four-star hotel in a major American resort city to address this issue. The convention was two 8-hour days ostensibly focused on education and training as well as two evening social receptions. Because the convention was organized by a single corporation interested in marketing its products, however, it often had the feel of a sales conference. The convention took place in the hotel's grand ballroom, where the 
first author and roughly 200 attendees of various rank from police forces across the United States and Canada sat at several dozen long tables. Each table faced the stage in the front of the ballroom, which was usually occupied by a single presenter and an LCD projection system, flanked by two large screens. Although the registration fee was \$200 per individual, many officers seemed to view the conference as a reward or vacation, as evidenced by the low attendance in the early morning sessions and the dramatic drop-off in attendance following the daily free lunch.

Data were gathered for this case study through participant observation (Jorgenson, 1989). Participation was easily achieved, as nothing was required of attendees other than payment of the registration fee. Except for the very limited question and answer sessions after most presentations, the clear norm for those in attendance was one of passive receptivity to presenters' speeches. Although the conference was marketed exclusively toward police officers and military personnel, no attendees or StunCo staff raised objections to researcher's attendance when he presented himself as a graduate student interested in police armaments, though he attempted to remain as inconspicuous as possible. As such, he was located between a known and unknown position as a researcher (Lofland \& Lofland, 1984) that allowed him the dual luxury of attending the conference openly and not under false pretenses, while also presenting an opportunity to "peer behind the veil" of a police event. Although this case study approach has its limitations, it affords a view of a cautious and guarded subgroup without the usual public filters, making it an interesting research site to examine the discourse and dispositions of a notoriously closed subculture.

Field notes were taken in the model of Katz's (2001) "luminous description," with extensive notes taken regarding what was said, reactions from those in attendance describing the physical surroundings, and the demeanor and appearance of presenters in addition to the self-reflexive notes of the first author's thoughts and reactions. The researcher also spent several hours each night filling in these notes with more detailed recollections, as well as analytic notes, to be expanded on after the conference. The typed notes resulted in 30 single-spaced pages. Both authors undertook a broad initial coding to intuitively identify the dominant themes prevalent throughout the conference. Although many topics were discussed throughout the weekend, the majority revolved around a core set of gendered appeals centered on three central themes involving idealized images of police officers, the use of force, and images of heroes and villains.

\section{Idealized Images}

Idealized images refers to instances in which StunCo presenters replaced the multiple conflicting realities of the police world with stylized stereotypes of officers as well as those who would question their mission and tactics. Much of the conference was composed of simple direct appeals from the exclusively White male presenters (a mixture of police officers, StunCo employees, and those who occupied both 
statuses) to the mostly White men who made up the overwhelming majority of the audience. These appeals highlighted the masculinity of the stunner. Officers were, in every case, described as male or in masculine terms, with women officers never entering the conversation. In addition, these appeals sidestepped the complex world of police decision making in favor of stylized stereotypical images of heroic officers and villainous outsiders, be they ruthless bad guys or meddling politicians.

The weekend's first presentation was from Commander Stan, a member of a large urban sheriff's department, and centered on the benefits of StunCo as opposed to the numerous other nonlethal weapons available to officers. He was the first among many presenters to explicitly invoke the race and gender of suspects and those who would question the use of the stunner. When discussing problems with other forms of weaponry, he noted that chemical irritants are useless against some populations. Somalis, he informs the audience, have "such good reflexes" they can move their eyes out of the way the instant they see you depress the trigger on a canister of pepper spray. When discussing the great strides StunCo has been making in developing ever-more sophisticated nonlethal technologies, he tells the audience that despite "religious tolerance and multiculturalism"—ostensible impediments to effective law enforcement-StunCo has been fortunate to continue their weapons development.

This racist/sexist resistance to multiculturalism and diversity was continued in other presentations. Another presenter, Lt. Dave (discussed at length below), questioned whether advances, such as the stunner, are weakening officers. He angrily noted that today officers are sent to special schools so that they "can talk to people correctly," which is training the "warrior mentality" out of them. The same presenter went on to further decry the loss of hypermasculinity in the face of increasing police professionalization and accountability. A slide in his PowerPoint presentation was entitled "Warriors-or-Bystanders" with bullet points reading "Cops are warriors; we're not allowed to lose" (emphasis in original). Sentences on the slides, such as "This mindset is essential to surviving and serving the public and they expect us to fight the bad guys so they don't have to," offer a revealing glimpse of the police subculture. The slide contained not only direct appeals to hegemonic masculinity but also to the deep mistrust of outsiders (in the notion that police must "survive" interactions with the public) and to the starkly dichotomous police worldview (with the use of "bad guys" to refer to suspects).

Lt. Dave and others continued the hypermasculine theme with oft-repeated references to police officers as warriors. A presenter on the conference's second day, Sgt. Gary, speaking about one city's process of adopting StunCo stunners for police use, echoed Herbert's (1998) discussion of "station queens." To firmly establish his credentials with street officers, the presenter repeatedly stressed that although he had to do hours of research and writing to make a successful proposal, he was in "culture shock" from doing all of that office work. He took pains to demonstrate that he was a street cop, even dedicating a presentation slide to read "Not an admin[istrative] 
boy-not a house mouse!" He told the audience that he was proud of his work on the beat because "those of us who are warriors, that's where we want to be."

During the "state of the company" presentation (a session during which company executives celebrated sales numbers and advances in design), the CEO of StunCo played a video of various StunCo staff getting shocked by the company's newest stunner, as a "light-hearted" end to the day's activities. Most of the video showed employees falling down in pain while uttering shrieks and long strings of obscenities. However, when a woman employee was stunned and simply fell to the ground (without screaming or begging them to turn it off), the crowd erupted into wild cheers and applause. After another woman is shown doing the same, the CEO paused the video and exclaimed that they (StunCo) will have to stop showing the women "taking it so well," as it makes the rest of them (e.g., male officers) look bad. Such examples suggest "external hegemony" — setting off the woman as other-in the construction of masculinity (Connell \& Messerschmidt, 2005; Yeung, Stombler, \& Wharton, 2006).

In addition, StunCo actively created and enforced a hegemonic masculinity in other ways. For example, a view of the firm's homepage and ultramodern headquarters was used as a placeholder slide between presentations. The gleaming steel structure features a three-story tall picture of a White male police officer in full riot gear standing at the "ready" on the building's exterior. Materials on the Web site discuss how the building represents the cutting edge of technological advances, boasting of the hypertechnological innovations available to all employees, but they also stress the gendered subtext of their operations.

\section{Force}

Although nonlethal weapons are designed to decrease brutality, the brutal aspects of police work have become an important defining characteristic of the hypermasculinity that is so essential to the police habitus. The theme of force highlights issues of hegemonic masculinity surrounding the ability to control and dominate others. It has been said that "police work has always been brutal; good police work, discreetly so" (Simon, 1991, p. 549). Such statements nicely illustrate the ideological tightrope that StunCo must walk.

Connell (1995) ties the development of technology to emerging forms of hegemonic masculinity. Computers, for example, were initially viewed as feminine, associated with the typists and keypunch operators of old — an arena exclusively reserved for women. Over time, however, such technologies were marketed directly to men, employing explicit masculine appeals in advertisements. With the increasing rationalization of advanced capitalism, the association between rationality and masculinity has, if anything, strengthened. Technology now represents a hyperrational form of development and is hence defined as hypermasculine. StunCo thus highlights the 
technological innovations and hyperrationality of its stunner. The firm also repeatedly emphasizes the symbolic power of its weapon; several presenters described suspects who were unafraid of police with drawn guns, but finally gave up at the sight of a stunner. Again, such arguments demonstrate StunCo's attempt to merge the two forms of hegemonic masculinity and craft the notion that hypertechnological weapons such as the stunner are actually more manly than traditional firearms.

\section{Heroes and Villains}

Appeals to heroes and villains are built on idealized images and represent attempts by StunCo presenters to recreate the dichotomous worldview of the police officer. StunCo presenters worked to portray themselves as contributing members of the police subculture not only by presenting ways in which the stunner would help officers but also by empathizing with the problems that police officers face, particularly the threat of regulation from unmasculine outsiders who cannot understand police work. By singling out particular heroes for recognition and villains for censure, presenters recognized and celebrated the boundaries of the subculture.

Although such tactics undoubtedly helped to align StunCo with its police audience, the company's most prominent appeal involved their shared distrust of "outside interference" into police work. Undoubtedly, StunCo feared that such interference could harm their company, but it was never framed in this way to the audience. Rather, as discussed below, it was typically presented in terms of how such outside influence would handcuff and castrate police departments and public safety.

In commenting on masculinity and gun ownership, Connell (1995) writes that "at both symbolic and practical levels, the defense of gun ownership is a defense of hegemonic masculinity" (p. 212). Connell's observation thus helps explain the near-hysteria about outside political regulation so prevalent at the conference. When weaponry such as the stunner can be portrayed as a gun-like symbol of one's masculine identity, any attempt to control its use is automatically seen as an attempt to emasculate the police. An incident at the conference reinforced this view. During a break, Rick, an English government official, explained to a small group of American officers that only 5\% of English officers are certified to carry any weaponry beyond a baton. The American police officers were astonished when he explained that English officers are not concerned about being shot or killed despite their lack of weaponry.

Although Amnesty and the ACLU were repeatedly criticized, the most acrimonious comments were reserved for politicians, judges, city councils, and political oversight boards. Many presenters expressed anger at being told what to do by judges, with the CEO perplexedly noting that "people can't accept it that the stunner is safe." California, the site of extensive debate on the use of CEDs, received special criticism. Buzz called the California Public Safety Committee the "Public Endangerment Committee." His claim that "the chairs in charge of the committees 
in both houses are the most liberal, San Francisco legislators" shows the heteronormative subtext of such complaints. The characterization of anti-StunCo opinions as "San Francisco" opinions-referencing a city well known for both its liberal tendencies and its large gay, lesbian, bisexual, and transgender population-was echoed in several presentations. [AQ: 1]

Apart from these villains, however, a notable heretic, Lt. Dave, emerged at the conference. During his presentation, he asserted that officers, especially younger recruits, have become overly dependent on stunners. One of his PowerPoint slides posed this question pointedly, asking "Does our latest generation of cops know how to fight?" When police officers become accustomed to working with a stunner, he argued, they tend to rely on it in all situations. What angers Lt. Dave the most, he went on to say, is that officers use the stunner to avoid physical confrontation: "how do I put this politically correct? [pauses] They don't wanna fight." This approach is masculine goading at its simplest; Lt. Dave was straightforwardly asking the audience if they were men who could do real police work or a bunch of "sissies" that needed to hide behind some fancy new invention. In challenging the masculinity of the stunner, the heretic drew StunCo's central problem into sharper relief. He offered a larger critique of the modern officer, but endeavored to leave room for the stunner's integration into a suitably masculine "old-school" vision of police work.

The clear undercurrent of Lt. Dave's presentation was a rejection of the technological form of masculinity and a questioning of the masculinity of officers who did not want to fight or engage in physical confrontation. He explained that when officers reach for their stunners, they often are making a mistake, asking "What should they be doing? Punching the snot out of the guy!" He played a series of training videos in which officers are attacked by a person in a "red man" suit (a padded suit used for physical combat training) and they all back away from confrontation and use their stunners. Again, he tells the audience that they "should've beaten the dog meat out of him" instead.

As much as the substance of the presentation, his diction evoked the hypermasculinity and warrior culture (Caulfield, 2001) of the police habitus. He spoke in clear, black-and-white imagery, consistently referring to suspects as "bad guys" and emphasizing that police are "warriors." He noted with some derision that police are now being sent to sensitivity training so "they can talk to people correctly," while the "warrior mentality" is being trained out of them. He seemed almost flabbergasted in reporting that often "[police departments] are talking about how not to use force" (emphasis his).

Lt. Dave seemed to serve as a hypermasculine accountant, engaging in what West and Zimmerman (1987) termed "gender assessment"- the idea that at all times we are performing gender, and therefore always are held accountable for our gendered performances. He was the sole presenter at the conference to hold the stunner accountable for being insufficiently masculine, resisting its incorporation into his view of proper policing. 
As such, this presentation represented a fundamental contradiction in the habitus of the police world. To be a "good cop" means to be a "good man," even for those who do not fit the strict dictates of hegemonic masculinity or who are not men (Myers, Forest, \& Miller, 2004). Furthermore, in this conception of masculinity, to be a "good man" means to be ready and willing to "beat the dog meat" out of anyone at anytime. At the same time, the habitus of policing is one that decries excessive force. Police officers know they are to avoid the use of excessive force and will likely face significant consequences if they do not. This situation is precisely the contradiction StunCo is trying to resolve through the positioning of their weapon as a powerful, yet safe, form of hegemonic hypermasculinity.

Of course, Lt. Dave was well aware that his views would be unwelcome at a StunCo convention. He repeatedly stressed that it was "an officer training problem, not a StunCo Incorporated problem" that leads to overreliance on CEDs. Furthermore, although an audience member thanked StunCo profusely for allowing such an important conversation to occur, the presenter mentioned several times that he was sure he would never be invited back because of his comments. In resisting StunCo's message that its stunner is a masculine modern weapon, he seemed to bring the unspoken skepticism or nagging doubts that may have been plaguing some attendees to the surface.

\section{Evidence and Parables}

The legitimizing evidence presented at the conference took the form of either quasiscientific data or more subjective but instructive parables that officers would do well to follow. Much of the external evidence involved extensive discussions on safety issues surrounding stunner use. Although great efforts were made throughout the conference to show how painful it was to be stung, including a live demonstration on volunteers from the audience, presentations on the stunner's safety were also common, ostensibly to appease administrators and outside parties. These presentations were founded on evidence that would be considered suspect by generally accepted scientific standards. For example, Officer Smith tested the effects of the stunner on improvised explosive devices (IEDs) by placing flash powder on top of an uncooked steak and then stinging the steak with the stunner. Although he termed it "backyard research" and admitted that it was "not scientific," he presented the results as offering conclusive evidence that the stunner would not set off an IED.

Apart from such quasiscientific presentations, quasilegal evidence was invoked to show how legal troubles were rarely the fault of the stunner. During a "Legal Update" presentation, Attorney Matt, a company lawyer, noted that the biggest problem StunCo faces regarding in-custody deaths is lost or unrecorded information that could prove that something other than the stunner was responsible for the deaths. Dr. Jim of In-Custody Death Prevention Co. later added that the reason StunCo is sued so often 
is not because of any problems with the stunner, but because of its deep pockets; they are typically perceived as the party with the most financial resources in the incident (relative, that is, to other suspects, individual officers, and the police department).

Although StunCo must make strong masculine appeals to police officers, it was in their interest to broaden such appeals when marketing CEDs to nonofficers. In this vein, much can be learned from the Web sites of StunCo and other nonlethal weapons manufacturers. Whereas the conference and Web sites aimed at law enforcement both play heavily on themes of masculinity and aggression, the civilians use stunner and other consumer-oriented CEDs were clearly targeted at women with what Stanko (1997) termed "safety talk," where women are encouraged to see all situations as potentially at risk from male [stranger based] violence. For example, in the "consumer" section of the Taser International Web site, a graphic of a woman jogging is accompanied by the caption, "There's a difference between running for health ... and running for your life," along with statistics on violent assault (Taser International, 2008).

Even a cursory examination of several leading weapon manufacturer's Web sites reveals the gendered nature of these products. Because the weapons marketed to consumers and to law enforcement often share similar technical specifications, the wide divergence in marketing strategies is especially telling. Not surprisingly, police-use CEDs are advertised along many of the same themes prevalent throughout the conference: hypertechnological development, improved officer safety, and reduced likelihood of lawsuits. For example, Stinger Systems boasts their CED lets "the law enforcement community . . . have the marketplace's newest technology at their fingertips" (Stinger Systems, 2008). Another industry leader, Panther Stun Guns, mimics the StunCo conference in claiming their weapons are "extremely powerful" and "loud and intimidating" yet "still non lethal and will not cause permanent damage" (Panther Stun Guns, 2008).

The discourse employed in marketing civilian-use CEDs could not be further from this presentation. Although occasionally pushing the hypertechnological developments they share with the police-use versions, the marketing toward civilians is overwhelmingly centered on personal and familial safety, separated from the appeals made to officers, and clearly aimed at women. Companies selling personal CEDs make use of stereotypical gendered and racialized themes in claims about their efficacy against "aggressors" who are likely "under the influence" (Black Cobra, 2008) and tend to use exclusively masculine pronouns when describing the ubiquitous "attackers" that fill their narratives (Security and Safety Supply, 2008).

This division between police and civilian use CEDs is upheld by many weapons manufacturers, some going to great lengths to separate their marketing appeals. Panther Stun Guns, for example, actually maintains two distinct Web sites: one for police and one for civilian self-defense sales (Personal Arms, 2008). Taser International, one of the biggest CED manufacturers, also maintains two separate 
sections of their Web site for police and civilians. Again, the section aimed at police officers emphasizes power and control, whereas the site's civilian section boasts that Tasers allows users to "control [their] own destiny," much like the "independent, self-reliant women they are." It also helps users to follow their "innate" commitment to protect their family.

It is important to note that during the entire StunCo conference for law-enforcement officers, the stunner's effectiveness as a self-defense weapon for women was never mentioned. Even during the "State of the Company" presentation, when Buzz the CEO celebrated sales to various sectors and the company's fantastic growth, there was no mention of the stunner as a self-defense weapon. The stunner is sold on the Web site as so technologically sophisticated and effective that even a female civilian can use it safely. If this were to be mentioned at the conference, however, it would completely undermine the gendered nature of the conference and all of the careful masculinity work performed for the law enforcement officers attending it. Hence, discussion of sales to civilians, especially women, was assiduously avoided.

Even the weapons themselves share this gendered division. The stunner advertised and sold to police officers bears a striking resemblance to traditional firearms and can be equipped with a number of hypertechnological accessories, such as precision laser sights. However, the personal-use stunner looks nothing like a gun and it features none of the high-tech add-ons available to the police. Again, this similarity is borne out by most nonlethal weapons manufacturers. Stinger Systems, which markets almost exclusively to police, shapes their weapon like a gun. In contrast, firms such as Cheetah Stun Guns, that market exclusively to civilians, promote their CEDs as the "size of a pack of cigarettes" that are "just the right size for your shirt pocket or the corner of your purse" (Cheetah Stun Guns, 2008), while others sell CEDs disguised as cell phones (TBO-Tech, 2008).

Taser International's weapons also starkly demonstrate this dichotomy. According to their Web site, the police-use taser actually appeared so similar to a handgun that bright yellow paneling was added to it after several officers across the nation had mistakenly grabbed their guns when they thought they were grabbing their tasers, with tragic consequences. Contrast this police taser with the feminized civilian-use taser (Taser International, 2008). The shape is more reminiscent of a woman's razor than a police-issue handgun, and it comes in a variety of feminized colors from "coral pink" to "leopard print." Undoubtedly, these differences are also attempts to reach other markets, notably youth markets (one can customize their taser further with an mp3-playing sport holster), but the gendering is certainly one of the most prominent aspects of the marketing of personal-use CEDs.

It is important to note that during the entire StunCo conference for law-enforcement officers, the stunner's effectiveness as a self-defense weapon for women was never mentioned. Even during the "State of the Company" presentation, when Buzz the CEO celebrated sales to various sectors and the company's fantastic growth, there was no mention of the stunner as a self-defense weapon. 


\section{Discussion}

Much has changed in policing during the last half-century, with processes of professionalization and militarization developing simultaneously (Garland, 2001; Kraska \& Kappeler, 1997). At the same time, civil society has moved toward greater racial, gender, and sexual equality, dramatically changing the world in which the police operate. These changes have been reflected in the criminal justice system to create a far different institutional environment than that which existed even a few decades ago. Our research demonstrates the ways a hypermasculine organization navigates and resists these changes toward greater gender inclusion.

The methodology employed in this study, observing one site for a short period of time, supplemented by examination of company Web sites and marketing materials, grants only limited exposure to the police subculture. Nevertheless, the information yielded in this context offers a revealing glimpse at how the conception of hegemonic masculinity is actively being restructured and adapted (Connell \& Messerschmidt, 2005). In showing how masculinity is invoked within a police subculture for commercial purposes, this research also complements and challenges notions of a criminal justice industrial complex (A. Davis \& Dent, 2001).

The often-blurry connections between public police and private corporations such as StunCo point to the problematic linkage that Davis and others (e.g., Kraska, 1996; Shelden \& Brown, 2000) have established. [AQ: 2] Although only one presenter at the conference explicitly identified himself as both a part-time public police officer and employee of StunCo, the fact that it was often difficult to tell which of the presenters were StunCo staff and which were public police officers speaks volumes to publicprivate hybrid model currently en vogue in the criminal justice system. Even the simple fact that private corporations such as StunCo are being awarded large contracts from public police departments both domestically and internationally (Lilly \& Knepper, 1992) strongly supports the existence of a criminal justice complex.

Nevertheless, we observed clear resistance to this neoliberal fusion of the private and the public throughout the conference. Officers such as Lt. Dave were obviously wary of any outsider attempting to influence the role of the police or the nature of police work. The existence of the conferences themselves points to the problematic and contradictory nature of the criminal justice industrial complex. Despite the neoliberal rhetoric of market-based solutions and inclusion of the private sector, private corporations must expend great effort to enter the closed hypermasculine police world. As such, StunCo was forced to tailor their message and appeal in myriad gendered ways in hopes of winning police contracts, which challenges simplistic notions of a monolithic criminal justice industrial complex. This study further raises questions of the criminal justice industrial complex as a gendered operation as well as complementing previous research on the gendered nature of marketing (e.g., Bordo, 1993; Kilbourne, 1999).

In the post-Miranda and post-Rodney King world, the police officer's conception of the world has necessarily evolved and adapted. Although in the 1960s and 1970s it was 
acceptable to blame crime on subjected minorities, dropouts, and other cultural scapegoats, this is no longer the case, at least in official discourse. Furthermore, as police tactics have been called into question, law enforcement has necessarily abandoned discourse and tactics that are unpalatable to the general public (Wilson, 2000). As a result, the police habitus is no longer starkly black and white, at least on the surface and within the public sphere. The hegemonic hypermasculinity of the police world must now negotiate the space between a desire to get tough on crime at all costs and a public increasingly resistant to the tactics that accompany such desires and practices.

Within such an environment, the Web sites of major manufacturers and events of the StunCo conference both confirm and challenge Connell's (1995) theories of a durable but fluid masculinity. They serve as a vivid example of how mastery of technology is cast as an inherently masculine pursuit. The incorporation of nonlethal technology into the hypermasculine police subculture exemplifies how firms negotiate hegemonic masculinity in crafting a commercial appeal.

Nevertheless, the CED case raises several questions that Connell (1995) does not explain. Chief among them is the stark durability of "traditional" police masculinity in the face of numerical gender diversity (U.S. Department of Justice, Bureau of Justice Statistics, 2003). Connell argues that the "active defense" of hegemonic masculinity "takes a variety of forms and often has to yield ground or change tactics" (p. 216). Although the StunCo conference clearly points to the variety of forms this masculinity can take, it also challenges the notion that defenders of hegemonic masculinity need ever cede ground. Rather, as has been demonstrated, new or differing masculinities can be reimagined as additions to a hybrid form of masculinity that loses none of its already existing rigidly defined aspects.

Following Connell (1995), Bird (1996) theorizes that heterosociality, or nonsexual interaction with members of the opposite sex, should diminish masculine hegemony, as men are more likely to display hegemonic masculinity in male-only situations. That StunCo framed their marketing appeal to increasingly diverse organizations around "traditional" police hypermasculinity would appear to contradict this point. Connell and Bird do not seem to offer an answer as to why this has occurred, though perhaps it is because of the exceptionally strong nature of the police subculture or a backlash against the increasing numbers of women entering policing.

The success of StunCo's approach suggests a similar paradox regarding violence. Connell (1995) notes that violence is essential to hegemonic masculinity, both to support or underpin male authority and to mark boundaries. Nowhere is this more apparent than in the hypermasculine world of the police habitus. Additionally, Enloe (1993), Kraska (1996), and others paint a convincing picture of the increasingly militaristic nature of the American police force and its inherent effects on both masculinity and weaponry. Yet the connection between violence and masculinity is directly contradicted by increasing police acceptance of CEDs weapons that are far less violent but more technically sophisticated than the standard police sidearm. Granted, the StunCo presenters went to great lengths to give the stunner a masculine 
appearance, even in the face of a heretic's challenge. Nevertheless, conference presenters never claimed it to be more violent than a traditional firearm, and in fact, made opposite claims in emphasizing the stunner's relative safety.

This study thus raises provocative questions for research on masculinities and policing. In particular, this study of nonlethal weapons documents the persistence of a privileged vision of masculinity in policing, while at the same time showing how a strong subculture absorbs and transmutes "less masculine" additions to the force.

\section{Note}

1. We use pseudonyms to protect the confidentiality of the individual presenters at the conference.

\section{References}

Acker, J. (1990). Hierarchies, jobs, and bodies: A theory of gendered organizations. Gender \& Society, 4, 139-158.

Amnesty International USA. (2006). USA Amnesty International's continuing concerns about taser use. New York: Author. Retrieved August 28, 2006, from http://www.amnestyusa.org/us/document.do?id= ENGAMR510302006

Beauchesne, L. (2001). Police outside the "true" police. Frontieres, 14, 43-48.

Bernstein, M., Kostelac, C., \& Gaarder, E. (2003). Understanding "heterosexism": Applying theories of racial prejudice to homophobia using data from a southwestern police department. Race, Gender, \& Class, 10, 54-74.

Bierne, P., \& Quinney, R. (Eds.). (1982). Marxism and law. New York: John Wiley. [AQ: 3]

Bird, S. R. (1996). Welcome to the men's club: Homosociality and the maintenance of hegemonic masculinity. Gender \& Society, 10, 120-132.

Bordo, S. (1993). Unbearable weight: Feminism, western culture and the body. Berkeley: University of California Press.

Bordua, D. J. (Ed.). (1967). The police: Six sociological essays. New York: John Wiley. [AQ: 4]

Bourdieu, P. (1977). Outline of a theory of practice. Cambridge, UK: Cambridge University Press.

Bouza, A. V. (1990). The police mystique: An insider's look at cops, crime, and the criminal justice system. New York: Plenum.

Carr, N. T., Hudson, K., Hanks, R. S., \& Hunt, A. N. (2008). Gender effects along the juvenile justice system: Evidence of gendered organization. Feminist Criminology, 3, 25-43.

Caulfield, S. L. (2001). Militarism, feminism, and criminal justice: Challenging institutionalized ideologies. In P. B. Kraska (Ed.), Militarizing the American criminal justice system (pp. 120-141). Boston: Northeastern University Press.

Chappell, A. T., \& Piquero, A. R. (2003). Applying social learning theory to police misconduct. Deviant Behavior, 25, 89-108.[AQ: 5]

Cheetah Stun Guns. (2008). Homepage. Retrieved September 9, 2008, from http://www.cheetahs tunguns.com/

Black Cobra. (2008). Frequently asked questions. Retrieved September 10, 2008, from http://www .blackcobrastunguns.com/faq.htm

Connell, R. W. (1995). Masculinities. Berkeley: University of California Press.

Connell, R. W., \& Messerschmidt, J. W. (2005). Hegemonic masculinity: Rethinking the concept. Gender \& Society, 19, 829-859. 
Davis, A., \& Dent, G. (2001). Prison as a border: A conversation on gender, globalization, and punishment. Signs, 26, 1235-1241.

Davis, J. A., \& Smith, T. W. (2007). U.S. General Social Survey (1970-2006) [Machine-readable data file]. Chicago, IL: National Opinion Research Center [Producer]; Storrs, CT.

Enloe, C. (1993). The morning after: Sexual politics at the end of the cold war. Berkley: University of California Press.

Feeley, M., \& Simon, J. (1992). The new penology: Notes on the emerging strategy of corrections and its implications. Criminology, 30, 449-474.

Garland, D. (2001). The culture of control. Chicago: University of Chicago Press.

Harris, R. N. (1973). The police academy. New York: Wiley.

Herbert, S. (1998). Police subculture reconsidered. Criminology, 36, 343-370.

Herbert, S. (2001). Hard charger or "station queen"? Policing and the masculinist state. Gender, Place, and Culture: A Journal of Feminist Geography, 8, 55-71.

Hibberd, J. (2006). Aftershocks. Amnesty International Magazine. Retrieved August 25, 2006, from http://www.amnestyusa.org/magazine/aftershocks.html

Jefferson, T. (1990). The case against paramilitary policing. Philadelphia: Open University Press.

Jorgenson, D. L. (1989). Participant observation: A methodology for human studies_Thousand Oaks, CA: Sage.

Kappeler, V. E., Sluder, R., \& Alpert, G. (1994). Forces of deviance: Understanding the dark side of policing. Prospect Heights, IL: Waveland Press.

Katz, J. (2001). From how to why: On luminous description and causal inference in ethnography (Part 1). Ethnography, 2, 443-473.

Kilbourne, J. (1999). Deadly persuasion: Why women and girls must fight the addictive power of advertising. New York: Free Press.

Kraska, P. B. (1996). Enjoying militarism: Political/personal dilemmas in studying U.S. police paramilitary units. Justice Quarterly, 13, 405-429.

Kraska, P. B., \& Kappeler, V. E. (1997). Militarizing American police: The rise and normalization of paramilitary units. Social Problems, 44, 1-18.

Lewer, N. (1999). Non-lethal weapons: Will non-lethal weapons offer kinder, gentler warfare or expand the options for armed forces to inflict pain and suffering? Forum for Applied Research and Public Policy, 14, 39-45.

Lewer, N., \& Davison, N. (2005). Non-lethal technologies-An overview. Disarmament Forum, 1, 36-51.

Lilly, J. R., \& Knepper, P. (1992). International perspective on the privatisation of corrections. Howard Journal of Criminal Justice, 31, 174-191.

Lofland, J., \& Lofland, L. H. (1984). Analyzing social settings. Belmont, CA: Wadsworth.

Martin, S. E. (1980). Breaking and entering: Policewomen on patrol. Berkeley: University of California Press.

Miller, S. L. (1998). Crime control and women: Feminist implications of criminal justice policy. Thousand Oaks, CA: Sage.

Miller, S. L., Forest, K. B., \& Jurik, N. C. (2003). Diversity in blue: Lesbian and gay police officers in a masculine occupation. Men and Masculinities, 5, 355-385.

Myers, K. A., Forest, K. B., \& Miller, S. L. (2004). Officer friendly and the tough cop: Gays and lesbians navigate homophobia and policing. Journal of Homosexuality, 47, 17-37.

Niederhoffer, A. (1969). Behind the shield: The police in urban society. New York: Anchor.

Panther Stun Guns. (2008). King Cobra stun gun. Retrieved September 10, 2008, from http://www .pantherstunguns.com/king_cobra_police_model.htm

Personal Arms. (2008). Home Page. Retrieved September 9, 2008, from http://www.personalarms.com/

Prokos, A., \& Padavic, I. (2002). There oughtta be a law against bitches: Masculinity lessons in police academy training. Gender, Work, and Organization, 9, 439-459.

Rappert, B. (2003). Non-lethal weapons as legitimizing forces? Portland: Frank Cass. 
Reiss, A. J., Jr. (1971). The police and the public. New Haven, CT: Yale University Press.

Security and Safety Supply. (2008). Stun guns. Retrieved September 9, 2008, from http://securityandsafety supply.com/product-self-defense/stunmaster-stun-gun.htm

Shelden, R. G., \& Brown, W. B. (2000). The crime control industry and the management of the surplus population. Critical Criminology, 9, 39-62.

Silver, A. (1967). The demand for order in civil society: A review of some themes in the history of urban crime, police, and riot. In D. J. Bordua (Ed.), The police: Six sociological essays (pp. 3-25). New York: John Wiley.

Simon, D. (1991). Homicide: A year on the killing streets. Boston: Houghton.

Skogan, W., \& Frydl, K. (Eds.). (2004). Fairness and effectiveness in policing: The evidence. Washington, DC: National Academies Press.

Skolnick, J. (1966). Justice without trial: Law enforcement in democratic society. New York: Wiley.

Skolnick, J. H., \& Fyfe, J. J. (1993). Above the law: Police and the excessive use of force. New York: Free Press.

Spitzer, S., \& Scull, A. T. (1982). Social control in historical perspective: From private to public responses to crime. In P. Bierne \& R. Quinney (Eds.), Marxism and law (pp. 235-250). New York: Wiley.

Stanko, E. A. (1997). Safety talk: Conceptualizing women's risk assessment as a "technology of the soul." Theoretical Criminology, 4, 479-499.

Steffans, L. (2005). The autobiography of Lincoln Steffans. New York: Heyday Books. (Original work published 1931) [AQ: 6]

Stinger Systems. (2008). About Us. Retrieved September 10, 2008, from http://www.stingersystems.com/ aboutstinger.aspx

Taser International. (2008). Home Page. Retrieved September 8, 2008, from http://www.taser.com [AQ: 7]

TBO-Tech. (2008). Cell phone stun guns. Retrieved October 7, 2008, from http://www.tbotech.com/ cellphonestungun.htm

Texeira, M. T. (2002). Who protects and serves me? A case study of sexual harassment of African American women in one U.S. law enforcement agency. Gender \& Society, 16, 524-545.

Uhnak, D. (1963). Policewoman. New York: Simon \& Schuster.

U.S. Department of Justice, Bureau of Justice Statistics. (2003). Local police departments, 2000. Washington, DC: U.S. Government Printing Office.

U.S. Department of Justice, Bureau of Justice Statistics. (2006). Citizen complaints about police use of force. Washington, DC: U.S. Government Printing Office.

West, C., \& Zimmerman, D. H. (1987). Doing gender. Gender \& Society, 1, 125-151.

Westley, W. A. (1970). Violence and the police. Cambridge, MA: MIT Press.

Wilson, C. P. (2000). Cop knowledge. Chicago: University of Chicago Press.

Wozniak, J. (2004). Winning the battle of Seattle: State response to perceived crisis. Illness, Crisis, \& Loss, 13, 129-145.

Yeung, K.-T., Stombler, M., \& Wharton, R. (2006). Making men in gay fraternities: Resisting and reproducing multiple dimensions of hegemonic masculinity. Gender \& Society, 20, 5-31.

Zimmer, L. (1987). How women reshape the prison guard role. Gender \& Society, 1, 415-431.

Jesse Wozniak is a doctoral candidate at the University of Minnesota. He studies policing, capitalism, and social control, and is currently working on a project examining a failed attempt at a moral panic surrounding the concept of excited delirium.

Christopher Uggen is a professor of sociology at the University of Minnesota. With Jeff Manza, he wrote Locked Out: Felon Disenfranchisement and American Democracy (2006, Oxford). He is currently at work on a comparative reentry project, an experimental study of low-level criminal records, and investigations of gender, substance use, and sexual harassment. 